DOI https://doi.org/10.30525/978-9934-26-114-5-75

\title{
ВИВЧЕННЯ ГОТОВНОСТІ ПСИХОЛОГО-ПЕДАГОГІЧНИХ ПРАЦІВНИКІВ ДО ПРОФІЛАКТИКИ ПОРУШЕНЬ ПИСЕМНОГО МОВЛЕННЯ У ДІТЕЙ
}

\author{
Мілевська О. П. \\ кандидат педагогічних наук, доцент, \\ дочент кафедри логопедії та спеціальних методик \\ Кам'янець-Подільський національний університет імені Івана Огієнка \\ м. Кам'янеиь-Подільський, Украӥна
}

Писемне мовлення $є$ основним навчальним умінням школярів та входить до комплексу соціально-значимих навичок людини. Читання та письмо слугують важливими засобами накопичення та відтворення знань, сприяють розвитку пізнавальної та особистісної сфер дитини.

Науковці О. Корнєв, Т. Єгоров, Р. Лалаєва, Н. Садовнікова та ін. Зазначають, що навички письма та читання формуються за умови достатнього рівня сформованості певних передумов, а саме: мовленнєвих (звуковимовний компонент, фонематичні процеси, лексико-граматичний компонент, зв'язне мовлення) та немовленнєвих (зорові та слухові функції, моторика пальців рук, вільна орієнтація в просторі та оперування просторовими поняттями тощо). У спеціальній психолого-педагогічній літературі ці передумови позначають терміном «функціональний базис читання і письма» (О. Корнєв, Е. Данілавічютє, В. Тарасун, М. Поваляєва, Л. Бартєнєва, Т. Вісковатова, О. Мазанова, I. Прищепова та ін.) [1; 3].

Традиційно, проблема профілактики порушень письма та читання розглядається у галузях логопедії (нейрологопедії), нейропсихології, a власне профілактичні заходи реалізуються як один із напрямів логопедичної роботи. Проте, на нашу думку, у розв'язанні цієї проблеми не менш важливою $є$ участь й інших фахівців - вихователів закладів дошкільної освіти, психологів дошкільних та шкільних навчальних закладів, вчителів початкових класів.

Відповідно, метою нашого дослідження було виявлення обізнаності психолого-педагогічних працівників у проблемі профілактики порушень письма та читання. У якості методики дослідження було обрано анкетування.

Ми припускали, що достатній рівень такої обізнаності є запорукою визначення правильних підходів до підготовки до навчання грамоти (стосовно вихователів, психологів дошкільних закладів) та безпосереднього навчання дітей грамоти (стосовно вчителів початкових класів, шкільних психологів) [4]. 
Розуміючи, що психолого-педагогічні працівники володіють певною професійною термінологією), ми сформулювали анкетні питання конкретно:

1. Дисграфія - це...(порушення письма; порушення читання; порушення мовлення)

2. Дислексія - це... (порушення письма; порушення читання; порушення мовлення; порушення рахунку)

3. Якщо у дитини страждають пізнавальні процеси, чи може це бути чинником для виникнення дисграфії? (так; ні)

4. Якщо дитина недостатньо орієнтується / не орієнтується в просторі, чи може це впливати на навчання письма? (так; ні)

5. Якщо дитина ліворука, чи має вона більшу схильність до проблем навчання письма? (так; ні)

6. Які види дисграфії ви знаєте? (відкрита відповідь)

7. Чи доцільно проводити профілактичну роботу у дитячих навчальних закладах для запобігання порушень письма, читання у дітей? (так; ні)

8. Які вам відомі ознаки порушень писемного мовлення? (відкрита відповідь).

Результати анкетування психологів, учителів початкових класів та вихователів дошкільних закладів показали, що ці фахівці мають певну обізнаність у проблемі профілактики порушень писемного мовлення розуміють ії значимість, періодично отримують відповідну інформацію на курсах підвищення кваліфікації чи під час відвідування професійних семінарів, тренінгів, засідань методичних об'єднань.

Разом з цим, усі три категорії опитаних схиляються до того, що така робота - це суто професійна діяльність логопеда.

Результати анкетування фахівців виявились наступними:

Виявлення обізнаності у термінології («дисграфія», «дислексія») показало, що вихователі дошкільних закладів та учителі початкових класів недостатньо їх розрізняють (лише по $31 \%$ респондентів правильно відповіли); натомість серед анкетованих психологів ми не виявили помилкових відповідей. Правильні відповіді психологів, на нашу думку, $\epsilon$ результатом фахової підготовки цих працівників, адже психологічні механізми лежати в основі структури навичок письма та читання відіграють, що без сумніву зацікавлює психологів.

Аналогічний стан відповідей на запитання щодо впливу порушень пізнавальних процесів на навчання грамоти - усі психологи (100\%) дали стверджувальні відповіді. Але 38 \% учителів засвідчили, що порушення пізнавальних процесів не є чинником у виникненні дислексій, дисграфій. Припускаємо, що деталізація психологічної структури навичок читання i письма $\epsilon$ недостатньо зрозумілою учителями початкових класів. 
На запитання щодо просторового орієнтування дітей та зв'язку цих функцій $з$ навчанням письма та читання ми не отримали однотипних відповідей. Так, 23\% психологів вважали, що порушення цих функцій не можуть впливати на навчання грамоти; $46 \%$ учителів теж заперечили такий зв'язок. Додатково, ми провели усне опитування, щоб з'ясувати правильність розуміння поставленого у анкетах запитання. Серед пояснень учителями і психологами своїх відповідей, ми отримали наступні: «при навчанні письма дитина не переміщзється у nросторі» - таке пояснення вказує на буквальне сприйняття категорії «просторове орієнтування» і недостатнє усвідомлення того, що базові просторово-орієнтувальні уміння лежіть в основі орієнтування на аркуші паперу; «порушене орієнтування у просторі пов'язане із плутанням лівого-правого, а на письмі дитина має зразок» - така відповідь теж вказує на неповне розуміння фахівцями графічної структури навички письма; «на письмі $і$ читанні дитина має маленький простір і постійно його сприймає зором» - 3 цього окремі респонденти роблять висновок, що порушитись просторове орієнтування за таких умов не може.

Відповіді на запитання про схильність ліворуких до порушень письма, як i у попередньому запитанні, певною мірою підтвердили недостатнє розуміння фахівцями особливостей лівопівкульної домінантності у дітей - 69\% учителів погодились, що не виникає за таких обставин додаткової схильності до проблем у навчанні письма. Але 68\% психологів вказали, що ліворукість може спричинити даткові труднощі навчання дітей грамоти.

Наступне запитання мало на меті виявити, чи обізнані психологи, учителі 3 видами дислексій, дисграфій; ми запропонували фахівцям самостійно назвати відповідні терміни. Зазначимо, що не усі опитані заповнили саме ці лінки у анкетах, і це було нами оцінено, як незнання цих термінів (69\% учителів і 61\% психологів). Серед інших відповідей ми зафіксували: оптичну дисграфію вказали $23 \%$ опитаних, акустичну - 23\%; аграматичну - $8 \%$; артикуляційно-акустичну - $8 \%$; моторну - 15\%; звукову - 8\%. Зрозуміло, що окремі відповіді некоректні. Отримані відповіді вказують на необхідність додаткового інформування фахівців у проблематиці порушень письма і читання, в т. ч., у механізмах цих порушень, що й відображено у традиційній термінології.

Неочікуваними виявились відповіді на питання стосовного місця проведення профілактичної роботи щодо порушень письма і читання (малось на увазі - дитячі навчальні заклади): лише 54\% респондентів погодились, що така робота повинна здійснюватися у цих закладах; решта 56\% заперечили. Склалось враження, що ці фахівці намагались зняти із себе відповідальність за результати профілактичної роботи вказаного спрямування. 
Найбільш коректними, хоч і не повністю правильними, виявились відповіді на останнє запитання (про ознаки порушень писемного мовлення). Серед вказаних ознак ми виявили наступні:

- на заміни, плутання і пропуски букв (100\% вчителів, 100\% психологів)

- на дописування зайвих букв чи елементів букв (100\% вчителів, $46 \%$ психологів)

- з'єднання прийменників зі словами (100\% вчителів, $23 \%$ психологів)

- неправильне написання закінчень (85\% вчителів, 15 \% психологів)

- на поганий почерк (53,5\% вчителів, 92\% психологів)

- »мало читає» (76\% вчителів, $61 \%$ психологів)

- »погано читає, не розуміє» (100\% вчителів, $61 \%$ психологів).

Таким чином, проведене нами анкетування учителів та психологів виявило недостатню обізнаність фахівців у проблематиці профілактики порушень писемного мовлення в цілому, що певною мірою пов'язано із недостатнім розумінням психологічної структури навичок письма, в тому числі недостатніми уявленнями про вікові норми розвитку психологічних механізмів, що лежать в основі формування навичок письма та читання.

Анкетування вихователів дошкільних закладів виявилось недостатньо результативним; незначна кількість відповідей свідчили про свідоме ставлення вихователів до проблеми профілактики порушень письма та читання у дітей. Разом 3 цим, саме вихователі наголосили на значимості формування у старших дошкільників звукового та складового аналізу, підготовки руки до письма, що є напрямами профілактики порушень писемного мовлення у дітей.

Резюмуючи результати проведеного анкетування зазначимо, що в цілому психолого-педагогічні працівники зарекомендували себе як перспективну аудиторія щодо практичної реалізації проблеми профілактики порушень писемного мовлення у дітей за умови проведення з ними спеціальної роз'яснювальної та навчальної роботи.

\section{Література:}

1. Бартєнєва Л.І. Підготовка дітей до оволодіння грамотним письмом. Дефектологія. 2002. № 2. С. 32.

2. Данілавічюте Е. Визначення рівня зорового сприймання дошкільників у зв'язку 3 підготовкою ї до опанування писемного мовлення. Теорія і практика сучасної логопедії. Вип.2. К.: Актуальна освіта, 2005. С. 126-131.

3. Поваляева М.А. Профилактика и коррекция нарушений письменной речи: качество образования. Ростов-н/Д: Феникс, 2006. 158 c.

4. Смирнова И.А. Логопедический альбом для обследования способности к чтению и письму. СПб.: Детство-Пресс, 2010. 64 с. 